\title{
Timing of cod reproduction: interannual variability and the influence of temperature
}

\author{
Jeffrey A. Hutchings, Ransom A. Myers \\ Science Branch, Department of Fisheries and Oceans, PO Box 5667, St. John's, Newfoundland, Canada A1C 5 X1
}

\begin{abstract}
We examined interannual variability in the timing of spawning of female cod Gadus morhua from 1947 to 1992 in 3 regions off Newfoundland, Canada, in the northwest Atlantic. Maturity data, assessed by visual examination of dissected gonads of cod collected by research trawls, were analysed with probit regressions to identify the day of each year on which $50 \%$ of females had ceased spawning (which we refer to as spawning time) on northern (Northwest Atlantic Fisheries Organisation (NAFO) Division 3L) and southern (3NO) Grand Bank and on St. Pierre Bank (3Ps). We minimized the bias in our estimates by separating sampling variability and interannual variation in age structure from true interannual variability in reproduction. Among regions, average spawning time (mean $\pm S D$ ) varied from Days $157 \pm 18$ (June 6) and $139 \pm 16$ (May 19) on northern and southern Grand Bank, respectively, to Day $135 \pm 24$ (May 15) on St. Pierre Bank. Interannual differences in spawning time were significant within 3L (1948-1991), 3NO (1947-1992), and 3Ps (1953-1987) (iikelihood ratio tests; $p<0.001$ ). Interannual variation in spawning time was significantly associated with variation in water temperature prior to spawning in $3 \mathrm{~L}$ and in 3Ps although the signs of the associations differed between regions, casting doubt on the hypothesis that the timing of cod reproduction represents an adaptive response to temperature change. The negative correlation between temperature and spawning time in $3 \mathrm{~L}$ can be explained by the positive influence of temperature on gonad development. In 3Ps, we attribute the early spawning dates in years characterized by cold bank temperatures to (1) a thermal barrier imposed by sub-zero temperatures on spawning migrations from the continental slope to the shelf, and to (2) increased rates of gonad development, and an earlier readiness to spawn, experienced by cod 'forced' to prolong their residence in warm slope waters. Our analyses indicate that cod spawning time varies significantly among years, demonstrate how the effects of temperature on cod reproduction depend on regional hydrography, and underscore the importance of separating variation in sampling protocol and age structure from true interannual variability in spawning time.
\end{abstract}

KEY WORDS: Gadus morhua - Interannual variability - Timing of reproduction - Newfoundland Northwest Atlantic

\section{INTRODUCTION}

The significance of short-term changes in biological variables is difficult to assess in the absence of longterm data on the variability of the traits in question. With notable exceptions [e.g. Darwin's finches on the Galapagos Islands (Grant 1986); brown trout Salmo trutta in an English stream (Elliott 1993)], temporal data on variation in life history, morphological, or behavioural traits of organisms in the wild are restricted to a few years (although potentially several generations) at best. The potential environmental causes of long-term temporal variability of biological traits can be explored when similar time series of 1 or more physical parameters are also available. Data on commercially exploited species represent a potentially valuable source of such time series because management usually entails the collection of biological and physical data in a consistent manner over many years or decades. Using a research data set that spans over $40 \mathrm{yr}$, we examine temporal differences in the timing of reproduction in a commercially important groundfish in 3 regions of the northwest Atlantic and assess the degree to which this variation is influenced by the environment.

Biological data on Atlantic cod Gadus morhua have been collected by research trawlers off the island of Newfoundland, Canada, since 1946. These data in- 
clude the age, size, sex, and state of maturity (assessed by visual inspection of dissected gonads) of random samples, stratified by fish length, from each trawl. Extensive data are available for Grand Bank off eastern Newfoundland and for St. Pierre Bank south of the island (Fig. 1). Water temperature data are also available for northern Grand Bank and St. Pierre Bank during the time period encompassed by the trawl surveys. Our objectives were (1) to describe interannual variation in the timing of cod reproduction, (2) to determine whether there are significant differences in the timing of spawning among years, (3) to assess the degree to which interannual variation in the timing of cod reproduction is associated with interannual variation in water temperature, and (4) to examine the relationship between variation in the timing of spawning and variation in seasonal migration patterns.

From an ecological perspective, data on temporal variation in reproduction can be used to test the hypothesis that spawning time of marine fishes is constrained by the necessity of maximizing the overlap between larval abundance and the seasonal supply of zooplankton (Cushing 1969). Based upon data on temperate species, Cushing (1969) posited that the date of spawning should be fixed to maximize the probability that some larvae will begin feeding during annually variable peaks in zooplankton abundance. The notion that the timing of larval emergence should

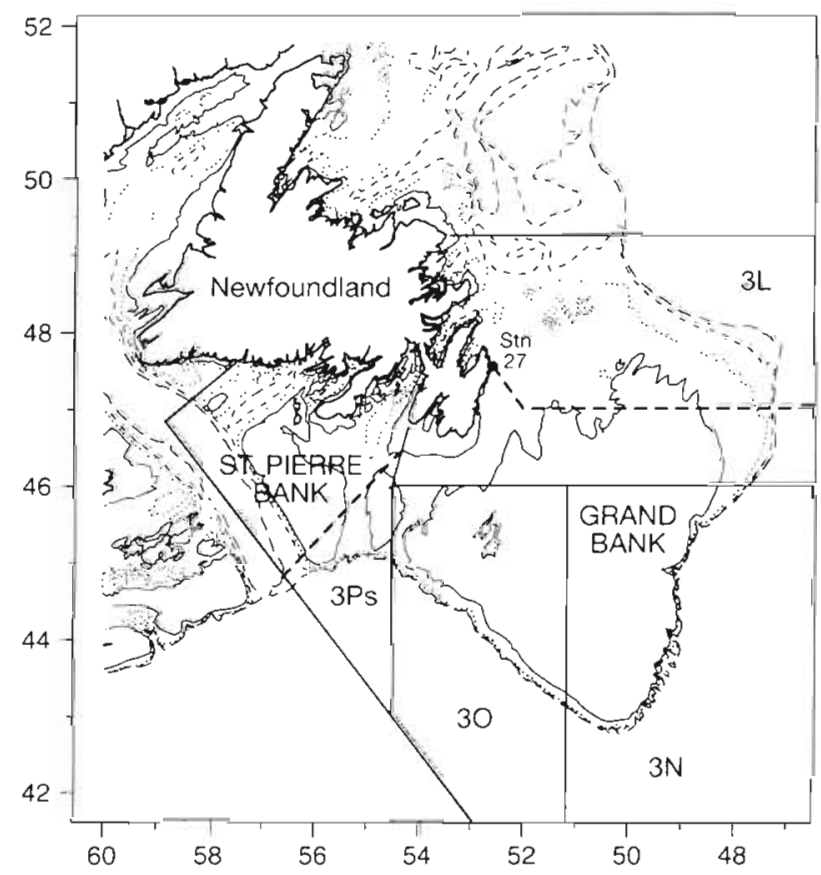

Fig. 1. The study region, including NAFO Divisions. Hydrographic transects in Divisions $3 \mathrm{~L}$ and 3Ps are indicated by thick dashed lines. Depth contours correspond to 100, 200, 300 , and $400 \mathrm{~m}$ match the timing of food abundance also underlies the hypothesis that a negative correlation between spawning time and water temperature represents an adaptive response by individuals to their environment (Satersdal \& Loeng 1987). We used our analyses of interannual variation in cod spawning times and water temperature to assess the validity of these hypotheses.

\section{MATERIALS AND METHODS}

\section{Estimation of annual spawning time}

Cod have been systematically sampled off Newfoundland by the Canadian Department of Fisheries and Oceans from 1946 to 1992 . Prior to 1972 , cod were sampled with research otter trawls along line transects. Since 1972, surveys have been randomly stratified by depth. Our analyses were restricted to regions in which ice cover was unlikely to prevent sampling of cod during prespawning and spawning periods. These regions were northern Grand Bank (Northwest Atlantic Fisheries Organization, or NAFO, Division 3L), southern Grand Bank (3NO), and St. Pierre Bank (3Ps). Monthly sample sizes and sampling years are given by Myers et al. (1993) and by Hutchings et al. (1993), respectively.

The reproductive state of female cod was assessed at sea, following the classification of Templeman et al. (1978), upon the removal and dissection of gonads. Individuals were identified as maturing, spawning, or spent according to the following criteria: maturing eggs opaque and visible to naked eye; spawning ovaries containing clear eggs, clarity being indicative of hydration and readiness for release (cf. Kjesbu 1989, Rijnsdorp 1989); spent - ovaries whitish-grey or bluish-grey, slack and often wrinkled, residual eggs often present. Sample sizes by reproductive state were: maturing females $\left(\mathrm{n}_{3 \mathrm{~L}}=2928, \mathrm{n}_{3 \mathrm{NO}}=2520, \mathrm{n}_{3 \mathrm{P}_{\mathrm{s}}}=2376\right)$, spawning females $\left(n_{3 L}=1167, n_{3 N O}=508, n_{3 P_{s}}=249\right)$, and spent females $\left(\mathrm{n}_{3 \mathrm{~L}}=5480, \mathrm{n}_{3 \mathrm{NO}}=2644, \mathrm{n}_{3 \mathrm{P}_{\mathrm{s}}}=764\right)$.

We defined time of spawning as the day of year on which $50 \%$ of mature females were in a spent state. We used a maximum likelihood probit regression to describe how the probability that a female will be spent is related to age (time of spawning is positively associated with age in cod; Hutchings \& Myers 1993), day of year, and year. To calculate these probabilities, we classified maturing and spawning females as 0 and classified spent females as 1 . Thus, the probability, $p$, of an individual aged a completing spawning on day $t$ of year $Y$ is

$$
p=\Phi\left(\beta_{0}+\beta_{1} a+\beta_{2} t+\beta_{Y}\right)
$$

where $\Phi$ is the cumulative distribution function for the standard normal distribution, $\beta_{0}$ is the intercept of the 
probit regression, $\beta_{1}$ and $\beta_{2}$ are the probit regression coefficients for the effects of age $(a)$ and day of year $(t)$, respectively, and $\beta_{Y}$ represents the deviation of the regression intercept attributable to the effects of year $Y$. Given that $0.5=\Phi(0)$, the mean spawning time in year $Y, t_{Y}$, is calculated from the estimates of the parameters in Eq. (1). To standardize the estimates, we calculated $t_{Y}$ for females of age $10 \mathrm{yr}$ (a reasonable historical median age at reproduction in Atlantic cod in the region; cf. Baird et al. 1992) to be

$$
\hat{t}_{Y}=-\left(\hat{\beta}_{0}+10 \hat{\beta}_{1}+\hat{\beta}_{Y}\right) / \hat{\beta}_{2}
$$

which gives the maximum likelihood estimate of $t_{Y}$.

It is unlikely that trawl samples collected by research vessels are independent of one another because such samples are clustered in space. That is, fish taken at a particular station (or haul) comprise a cluster and are more likely to be similar to one another with respect to size, age, and reproductive status than fish sampled at random from the population. Failure to account for cluster structure in such data (i.e. high within-cluster correlations) can lead to underestimates of the true sampling variance (Rao \& Scott 1992). To account for within-cluster correlations, we used the method suggested by Rao \& Scott (1992) for the analysis of clustered binary data. The standard error estimates of $\beta_{Y}$ were inflated by an amount equal to the estimated variance due to cluster sampling divided by the estimated binomial variance.

We excluded some years from the analyses because of insufficient sampling during spawning. The values of $\beta_{Y}$ for these years were characterized by inordinately large standard errors, i.e. 3 to 5 orders of magnitude greater than all other values. Of the 47 years of available data, sample sizes were sufficient within years to estimate spawning time for 35,30 and $29 \mathrm{yr}$ in $3 \mathrm{NO}, 3 \mathrm{~L}$, and 3Ps, respectively.

Water temperature data. To assess the effects of water temperature on spawning time, we restricted our analysis to the 6 mo periods most likely to encompass gonad development and reproduction. Based on the information provided by Myers et al. (1993), these time periods were January through June for St. Pierre Bank and southern Grand Bank, and February through July for northern Grand Bank.

The temperature series for St. Pierre Bank was compiled from all available temperature records from the Marine Environment Data Services (MEDS), Department of Fisheries \& Oceans, Ottawa, Ontario, Canada. We used only those temperatures recorded over the bank that were further than $20 \mathrm{~km}$ from the continental shelf break because of strong temperature gradients at the shelf break. We report the average of all temperatures recorded from January through June at a depth of $50 \mathrm{~m}$, the minimum depth on St. Pierre Bank (there was no detectable seasonal cycle at or below this depth on the bank from January to July; Drinkwater \& Trites 1986).

Temperature data for northern Grand Bank were those measured at a hydrographic station off St. John's, Newfoundland (Stn 27; Fig. 1). This station has been sampled approximately twice monthly since 1946. Temperatures recorded at Stn 27 are well correlated with sea temperatures throughout northern Grand Bank (Petrie et al. 1992). For each year, we averaged all temperatures recorded from February through July at depths of 75 and $100 \mathrm{~m}$ which represent the bottom or near-bottom depths for most of Grand Bank.

The existence of strong temperature gradients prevented us from constructing a reliable time series for southern Grand Bank. Temperatures recorded within weeks of one another between January and June often differed by 5 to $6^{\circ} \mathrm{C}$, regardless of depth (MEDS, 1946 to 1992). In addition, the bank was not sampled sufficiently to separate annual from geographic variation in temperature. Thus, associations between water temperature and spawning time were examined only in $3 \mathrm{~L}$ and $3 \mathrm{Ps}$.

Water temperature and spatial distribution of cod. Temperature might influence the timing of cod reproduction by affecting their spatial distribution. To irvestigate this possibility in the northern Grand Bank and St. Pierre Bank regions, we examined the relationship between water temperature and the biomass of cod caught by research trawls on the continental shelf relative to the biomass of cod on the continental slope prior to spawning. Tagging studies indicate that cod from these 2 regions represent separate populations (Templeman 1974).

Biomass data for cod on northern Grand Bank (3L) were available for April and May (Baird et al. 1992), the 2 mo immediately preceding the month of peak spawning (Myers et al. 1993). The shelf and slope data included all fish captured in research otter trawls at depths of 57 to 92 and 276 to $366 \mathrm{~m}$, respectively (depth ranges correspond to those given by Baird et al. 1992). Biomass estimates for the shelf and slope waters represented the total biomass of cod captured from all 'strata' (survey areas delimited primarily on the basis of depth) sampled in each of the 2 depth categories. Cod in the shelf and slope waters were sampled randomly from 5 and 6 strata, respectively. Data were available from 1978 to 1991, although some strata were not sampled during some years. The biomass totals for nonsampled strata were estimated from a multiplicative model which included year and stratum effects (Gavaris 1980). Yearly biomass estimates that include nonsampled strata are termed 'incomplete' data in our analyses. The temperature data were those measured at Stn 27. Temperature-depth profiles for the shelf and slope off northern Grand Bank were obtained from 
data recorded along a hydrographic transect extending from St. John's east to Flemish Cap (Fig. 1; data summarized in Templeman 1975).

Biomass and temperature data for St. Pierre Bank were obtained from Canadian and French research data. The Canadian temperature data (which included some data collected by other countries) were those previously described from MEDS (i.e. average temperature from January to June at $50 \mathrm{~m}$ depth). The French data were obtained from hydrographic surveys (described by Moguedet \& Mahe 1991) that were conducted along the same transect (Fig. 1) from 1978 to 1990 and were sampled at the same time every year (usually midMarch; range for all years was 21 February to 21 March). We used the average absolute temperatures recorded between depths of 0 and $99 \mathrm{~m}$ on the bank. Temperature-depth profiles for the shelf and slope waters of St. Pierre Bank were also obtained from Moguedet \& Mahé (1991). Biomass data from Canadian random-stratified surveys are available for 1972 to 1991 (Bishop et al. 1991). Shelf and slope waters encompassed depths of 56 to 90 and 271 to $365 \mathrm{~m}$, respectively (depth ranges correspond to those given by Bishop et al. 1991). Given that sampling dates varied from late January to mid-June, we included only those years for which samples were available in the 2 mo immediately preceding spawning (i.e. late January to late March). Random-stratified surveys by French research vessels were conducted during February \& March each year from 1978 to 1991 (Moguedet \& Mahé 1991; data available from Bishop et al. 1991). Both the French and Canadian data for St. Pierre Bank included years in which strata were incompletely sampled.

Statistical analyses. Likelihood ratio tests were used to determine whether significant interannual variation in cod spawning time existed within each of the 3 geographical regions. We calculated the log-likelihood ratios of the probit model with and without year effects $\left(\beta_{Y}\right)$ and then calculated the G-statistic (whose distribution approximates the $\chi^{2}$-distribution) which is equal to twice the difference in the log-likelihood ratios (Sokal \& Rohlf 1981). Weighted linear regressions were used to analyse the associations between water temperature and spawning date and between water temperature and the ratio of cod biomass on the continental shelf relative to that on the continental slope.

\section{RESULTS}

\section{Timing of cod spawning}

There was significant interannual variation in the timing of cod spawning on northern (3L) and southern (3NO) Grand Bank and on St. Pierre Bank (3Ps) (Fig. 2);
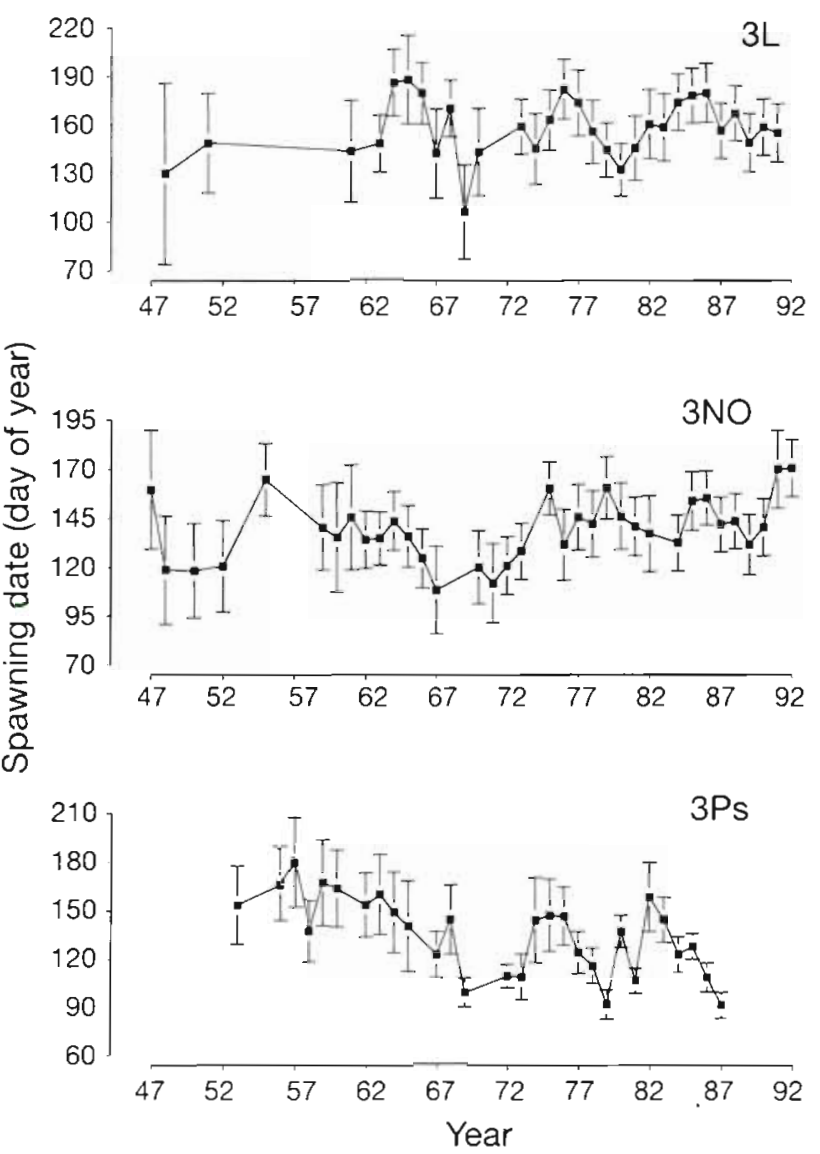

Fig. 2. Gadus morhua. Interannual variation in spawning date (time at which $50 \%$ of reproductive females are in a spent state) of Atlantic cod in NAFO Divisions $3 \mathrm{~L}$ (northern Grand Bank), 3NO (southern Grand Bank), and 3Ps (St. Pierre Bank) (data are means $\pm 1 \mathrm{SE}$ )

inclusion of year effects significantly reduced the loglikelihoods of the probit regressions in each of the 3 regions (3L: $G=181.74>\chi_{|29 ; 0.001|}^{2}=58.30 ; 3 \mathrm{NO}: G=$ $187.67>\chi^{2}{ }^{344 ; 0.001]}=65.25 ; 3 \mathrm{PS}: G=192.44>\chi^{2}{ }_{\{28 ; 0.001\}}=$ 56.89). Spawning on northern Grand Bank (mean Day of year $\pm \mathrm{SD}=157 \pm 18$, i.e. June 6 ) occurred significantly later $\left(F_{[2,91]}=10.29, \mathrm{p}<0.001\right)$ than spawning on southern Grand Bank (Day $139 \pm 16$, i.e. May 19) and on St. Pierre Bank (Day $135 \pm 24$, i.e. May 15 )

There are a number of similarities in the ways in which spawning time varied annually among regions. Spawning was progressively earlier from either the late 1950 s (3NO and 3Ps) or the mid-1960s (3L) until the late 1960s. From the late 1960s to the mid-1970s, spawning occurred progressively later in each region before occurring earlier again in $3 \mathrm{~L}$ and $3 \mathrm{Ps}$ until the late 1970 s. Since the early 1980 s, spawning times have changed relatively little in $3 \mathrm{~L}$, have become somewhat later in 3NO (particularly in the early 1990s), but have occurred progressively earlier in 3PS. 


\section{Water temperature and spawning time}

Water temperatures during the months of gonad development and reproduction varied dramatically among years on both northern Grand Bank (3L) and St. Pierre Bank (3Ps) (Fig. 3). Although no long-term pattern was evident on northern Grand Bank, temperatures lower than the 1946 to 1991 average of $-1.2^{\circ} \mathrm{C}$ were most evident in the early and late 1970 s and from 1982 to 1991. A long-term decrease in temperature of approximately $2{ }^{\circ} \mathrm{C}$ is evident on St. Pierre Bank from the early 1950 s to the late 1960 s. Since the late 1960 s, St. Pierre Bank has experienced 2 periods of progressive increases and decreases in temperature with the dramatic reduction from 1982 to 1987 almost equalling the entire long-term variation in temperature from 1952 to 1987.

Time of cod spawning on northern Grand Bank and St. Pierre Bank was closely related to water temperatures on the banks prior to cod reproduction (Fig. 3). Interestingly, the general patterns of association between spawning date and temperature differed between regions. In 3L, low temperatures were associated with delayed spawning; in 3Ps, low temperatures were

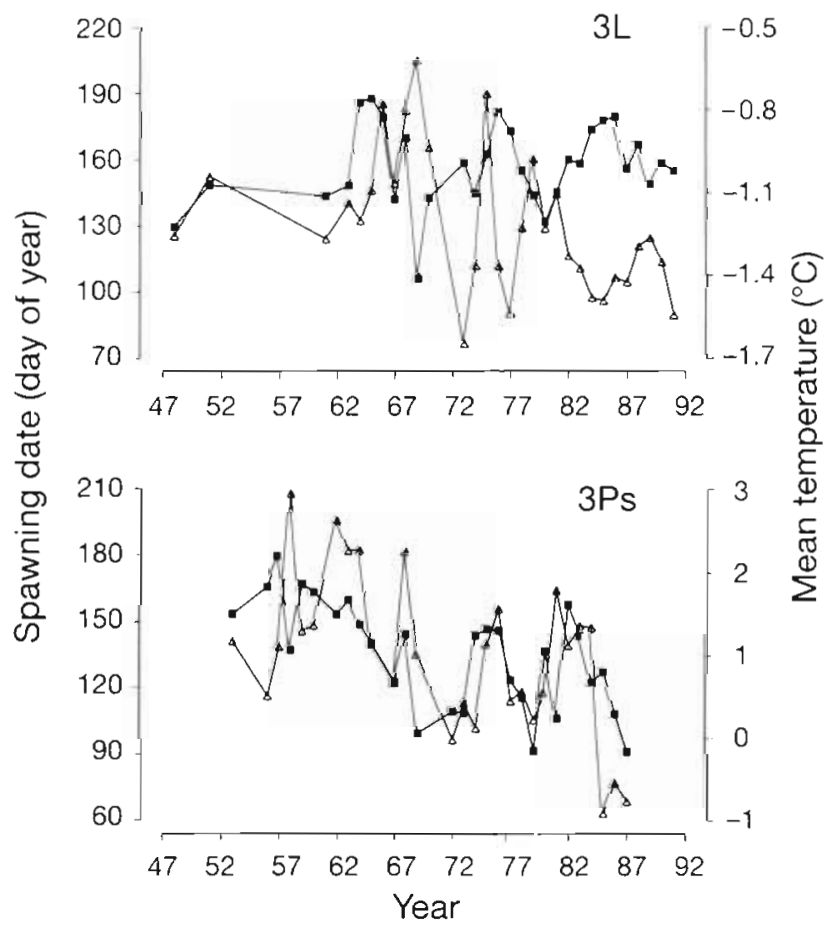

Fig. 3. Gadus morhua. Interannual variation in spawning time (-) and water temperature ( $\Delta$ ) during gonad development and reproduction of Atlantic cod in NAFO Divisions 3L (northern Grand Bank) and 3Ps (St. Pierre Bank). Water temperature data in $3 \mathrm{~L}$ were recorded at Stn 27 (see Fig. 1) at depths of 75 and $100 \mathrm{~m}$ from February to July. Water temperature data in 3Ps (St. Pjerre Bank) represent the annual means of all temperature records at $50 \mathrm{~m}$ from January to June (data from the Marine Environment Data Services)

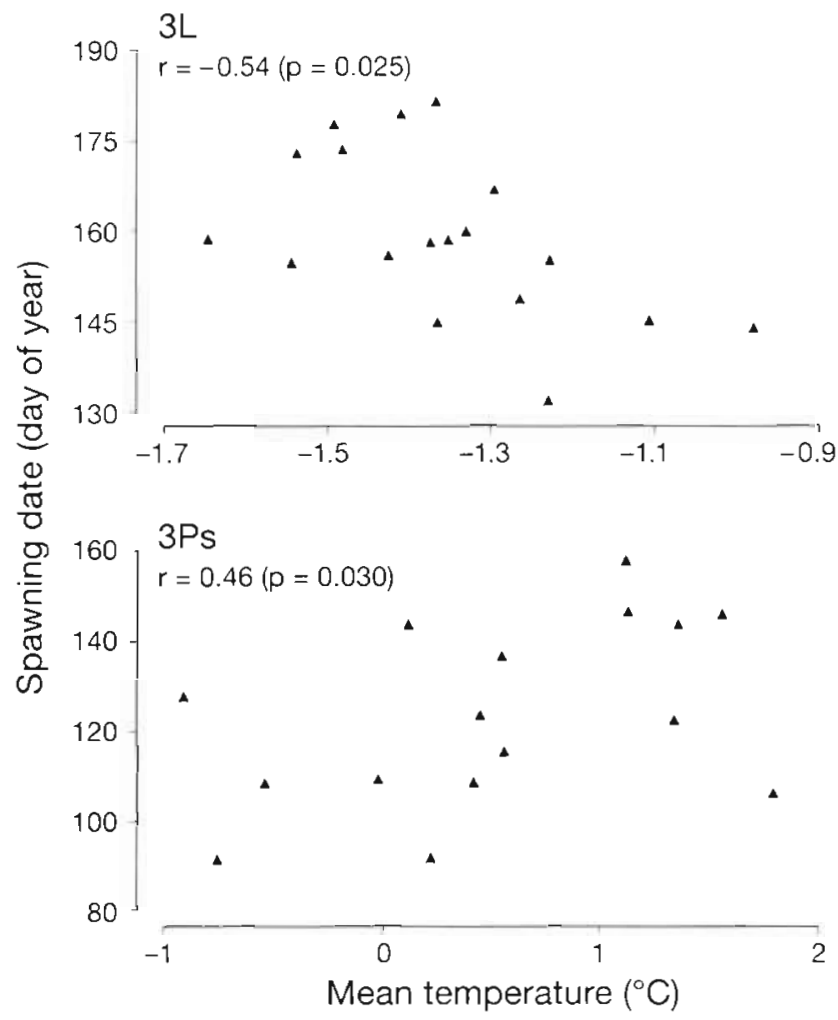

Fig. 4. Gadus morhua. Relationship between spawning date of female Atlantic cod and water temperature during gonad development and reproduction in 3L (northern Grand Bank) and 3Ps (St. Pierre Bank). Data for 3L are from 1973 to 1991; data for 3Ps are from 1972 to 1987

associated with early spawning. These relationships were particularly strong after 1972, the years in which cod sampling was randomly stratified. Including only the post-1972 data (because of the increased reliability of spawning date estimates determined from random samples) and including years in which temperature data existed for at least 5 of the 6 months prior to and including reproduction, there were significant associations between spawning date and water temperatures on northern Grand Bank and St. Pierre Bank (Fig. 4). Spawning date was negatively correlated with temperature in 3L $\left(F_{[1,16 !}=6.12, r=0.54, p=0.025\right)$ but positively correlated with temperature in $3 \mathrm{Ps}\left(F_{[1,14]}=5.86\right.$, $r=0.46, p=0.030)$. Although significance levels can be underestimated by autocorrelated times series data, neither the first-order autocorrelation coefficients of the independent variable ( $3 \mathrm{~L}: \mathrm{r}=0.25, \mathrm{p}=0.35 ; 3 \mathrm{Ps}$ : $\mathrm{r}=0.44$, $p=0.10$ ) nor those of the second- to twelfth-order coefficients $(p>0.05)$ were significant.

\section{Water temperature and spatial distribution of cod}

From 1978 to 1991, variation about the long-term (1946-1991) mean temperature in 3L (Stn 27, Feb-Jul 


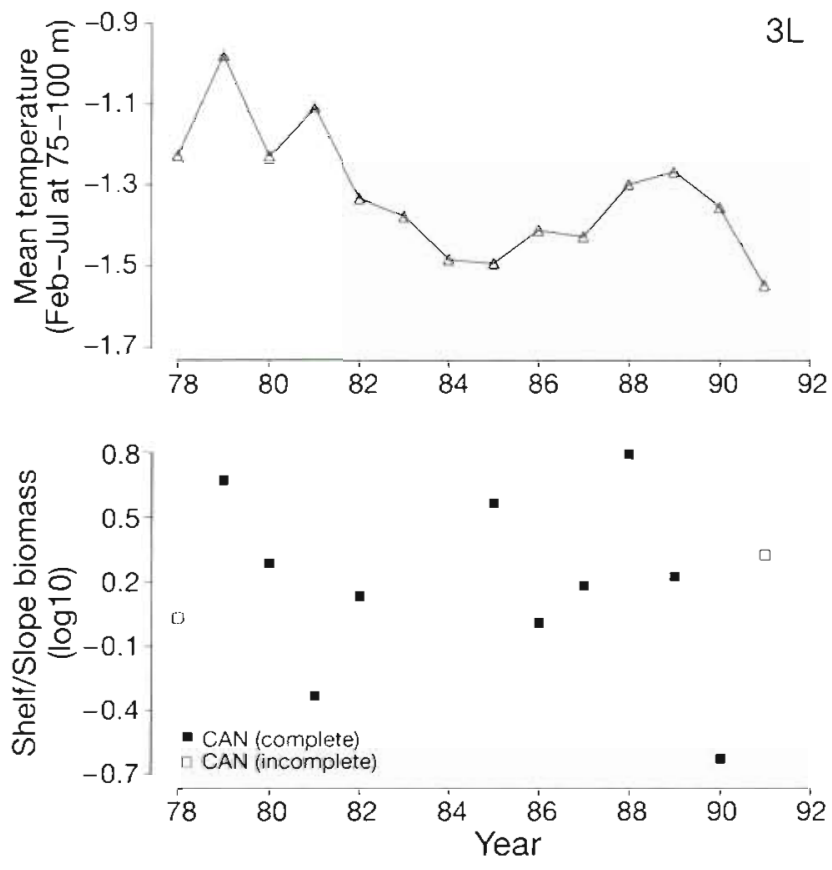

Fig. 5. Gadus morhua. Interannual variation in water temperature $\left({ }^{\circ} \mathrm{C}\right)$ and the biomass of Atlantic cod on the continental shelf $(57$ to $92 \mathrm{~m}$ ) relative to that on the continental slope (276 to $366 \mathrm{~m}$ ) in NAFO Division 3L (northern Grand Bank). Biomass data are from Canadian (CAN) research surveys (for definitions of complete and incomplete data, see 'Methods')

at 75 to $100 \mathrm{~m}$ ) exceeded $0.5^{\circ} \mathrm{C}$ with generally higher temperatures evident to 1981 (maximum: $-0.98^{\circ} \mathrm{C}$ in 1979) and the lowest temperature recorded in 1991 $\left(-1.62^{\circ} \mathrm{C}\right)$ (Fig. 5). Although the biomass of cod on the shelf relative to that on the slope differed more than 10-fold from 1978 to 1991 in 3L (Fig. 5), these differences were uncorrelated with water temperature $\left(F_{[t, 10]}=0.01, \mathrm{r}=0.02, \mathrm{p}=0.947\right)$.

In contrast to $3 \mathrm{~L}$, water temperature in 3Ps from 1972 to 1991 was significantly associated with the relative biomass of cod on the shelf (Figs. 6 \& 7). The temperature profile in 3Ps is marked by 2 distinct time periods. Temperatures (Jan-Jun at $50 \mathrm{~m}$ ) from 1972 to 1984 were significantly higher (mean $\pm \mathrm{SD}: 0.82 \pm 0.59^{\circ} \mathrm{C}$ ) than they were from 1985 to $1991\left(-0.59 \pm 0.48 ; F_{\mid 1,18\}}=\right.$ $28.90, \mathrm{p}<0.001)$. The $1.4^{\circ} \mathrm{C}$ decrease in temperature between these periods was associated with considerably fewer cod on the shelf (Fig. 6). The relative biomass of cod on the shelf varied by almost 3 orders of magnitude from 1972 to 1991 (total biomass declined by less than 1 order of magnitude during this period; Bishop et al. 1991). The relative biomass of cod on the shelf increased significantly with shelf water temperatures for the combined Canadian and French data (all data: $F_{\{1.25\}}=11.42, \mathrm{r}=0.56, \mathrm{p}=0.002$; complete data only: $F_{[1,12]}=8.90, \mathrm{r}=0.65, \mathrm{p}=0.01$ ) (Fig. $7 \mathrm{~B}$ ). The pos-
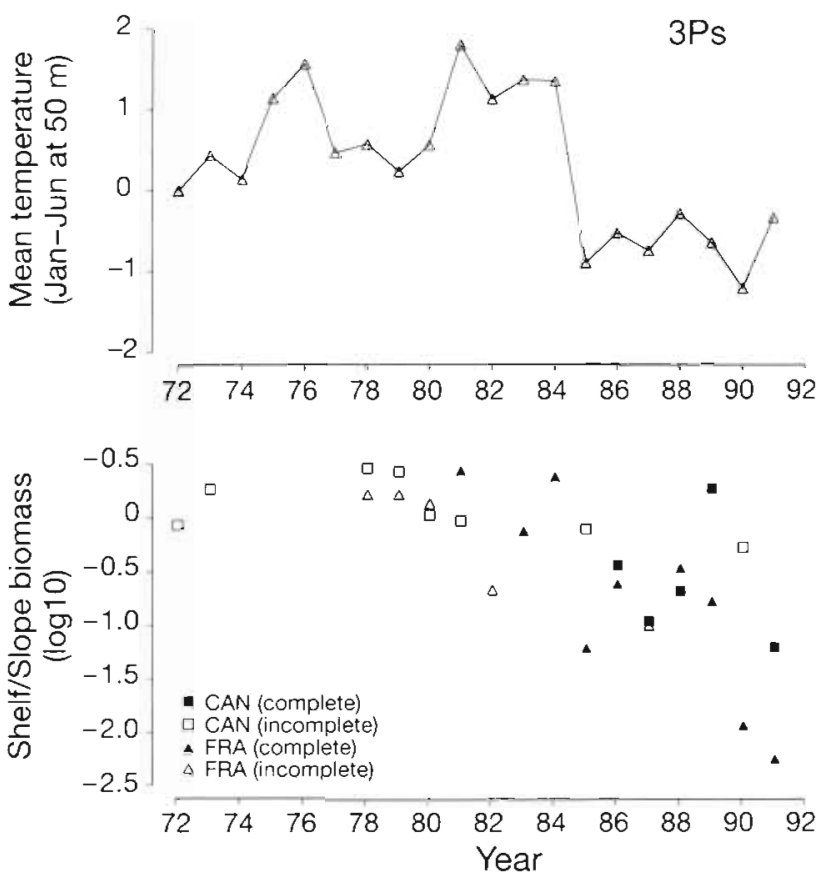

Fig. 6. Gadus morhua. Interannual variation in water temperature $\left({ }^{\circ} \mathrm{C}\right)$ and the biomass of Atlantic cod on the continental shelf $(56$ to $90 \mathrm{~m}$ ) relative to that on the continental slope $(271$ to $365 \mathrm{~m}$ ) in NAFO Division 3Ps (St. Pierre Bank). Biomass data are from Canadian (CAN) and French (FRA) research surveys (for definitions of complete and incomplete data, see 'Methods')

itive association between cod biomass on the shelf and water temperature prior to reproduction was particularly strong for the French data in which biomass and temperature were recorded during the same time period annually $\left(F_{[1,10]}=17.20, \mathrm{r}=0.80, \mathrm{p}=0.002\right)$ (Fig. 7C).

\section{DISCUSSION}

\section{Interannual variation in spawning time}

The timing of spawning by Atlantic cod off Newfoundland differs significantly among years. In general (68\% probability, i.e. 2 SD), mean spawning time would be expected to vary up to 34 to $48 \mathrm{~d}$ on Grand Bank and St. Pierre Bank, respectively. To our knowledge, the existence of statistically significant variation has not been explored in any other analyses of interannual variation in spawning time in fishes. A serious shortcoming of virtually all such analyses is the failure to incorporate the spatial and temporal biases characteristic of cluster sampling that occur in both marine and freshwater environments (cf. Myers et al. 1986) into variance estimates of spawning time. Many estimates of spawning date are further complicated by 


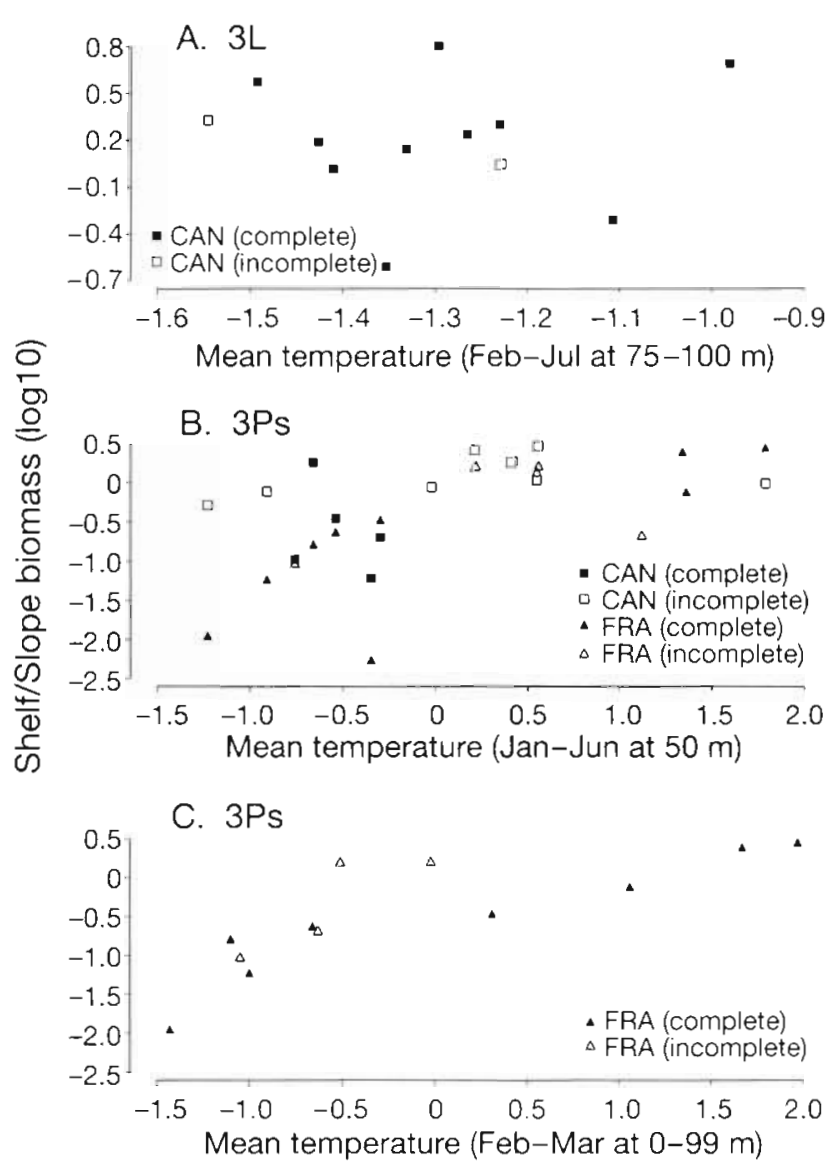

Fig. 7. Gadus morhua. Relationships between biomass of Atlantic cod on the continental shelf relative to that on the slope and water temperature $\left({ }^{\circ} \mathrm{C}\right)$ prior to reproduction. (A) Data for 3L (northern Grand Bank) from 1978 to 1991 (B) Canadian (CAN) and French (FRA) data for 3Ps (St. Pierre Bank) from 1972 to 1991 (C) French data collected during February-March of each year in 3Ps from 1978 to 1990

the use of commercial catch data (e.g. Cushing 1969) and by inconsistent use of the phrase 'peak spawning period' (e.g. Sinclair \& Tremblay 1984, Page \& Frank 1989).

Given the lack of consistency in the estimation of spawning time, it is difficult to assess the degree to which interannual variability in reproduction is a feature of marine fish populations. An additional complication is the general failure to account for interannual variation in age structure. A 61 yr time series (1928-1988) of egg data collected from commercial catches in the Lofoten fjord, Norway, indicates that mean peak spawning date of cod varied by at least $30 \mathrm{~d}$ (Ellertsen \& Solemdal 1990). However, for a 7 yr period (1976-1982) in the same area, research egg survey data show remarkably little variation in median spawning date (Pedersen 1984). Cushing's (1969) interpretation that the timing of peak catches of cod in Lofoten lacks interannual variation over $75 \mathrm{yr}$
(1894-1968) must be tempered by an absence of appropriate statistical analysis and by the problematic biases associated with commercial catch data. Jónsson (1982) documented substantial interannual variation in the beginning of the spawning season of cod off the southwest coast of Iceland. These research data were calculated as deviations (up to $28 \%$ ) from the longterm (1954-1981) mean of the percentage of cod with 'running' gonads from 1 March to 15 April. Of 12 herring Clupea harengus populations for which several years of egg survey data are available (Sinclair \& Tremblay 1984), peak spawning periods within populations can differ up to $45 \mathrm{~d}$ among years (e.g. southern Gulf of St. Lawrence population for which $27 \mathrm{yr}$ of data were available; see also Lambert 1987). Page \& Frank (1989) document different levels of interannual variation in time of peak spawning in 2 stocks of haddock Melanogrammus aeglefinus off eastern Canada and provide a summary of interannual variation in spawning time for other north temperate and high latitude fish populations.

The existence of interannual variability in spawning time has both ecological and management implications. Cushing (1969) postulated that spawning time should be relatively invariant from year to year so that 'the population has the best chance of profiting by the variability of the production cycle' (Cushing 1969: p. 91). A corollary of this hypothesis is the suggestion that, in the presence of low temperatures, delayed reproduction represents an adaptive response which increases the likelihood that larval emergence will match a presumably delayed zooplankton bloom (Sæetersdal \& Loeng 1987, Ellertsen \& Solemdal 1990). These hypotheses are not supported here given the different signs of the significant correlations between temperature and spawning time. From a management perspective, it has generally been assumed that spawning time is roughly constant among years and that closure of commercial fisheries during spawning would be an effective means of increasing the number of reproducing females and, hence, recruitment to the fishery. The existence of significant interannual variation in the timing of spawning suggests that such a management policy may have limited success for Atlantic cod off Newfoundland unless it effected a closure several months in duration.

\section{Effects of water temperature on spawning date}

The influence of water temperature on the timing of cod reproduction off Newfoundland differs between regions. In $3 \mathrm{~L}$, spawning is delayed in cold years. Yet in 3Ps, lower temperatures prior to reproduction are associated with earlier spawning. This discrepancy in 
the effects of temperature on spawning date can be attributed to regional differences in the thermal gradient between shelf and slope waters. We contend that water temperature acts as a thermal barrier to spawning migrations and as a physiological regulator of the rate of gonad development. We illustrate the relative importance of these migration and energetic constraints on cod spawning with reference to NAFO Divisions 3L and 3Ps off Newfoundland.

Cod spawn primarily on the continental shelf, rather than the continental slope, off Newfoundland (Hutchings et al. 1993). Tagging studies in 3Ps indicate that cod overwinter in slope waters before migrating onto adjacent St. Pierre Bank to spawn (Templeman 1962 , Templeman \& Fleming 1962). In 3L, cod spawning on northern Grand Bank overwinter either on the shelf or on the slope (Templeman 1979). Thus, spawning migrations, where they exist, occur from slope to shelf waters. If slope waters are generally warmer than shelf waters in late winter and early spring, steep thermal gradients between these waters could delay migration to spawning areas. In 3Ps, as indicated by the hydrographic profiles of Moguedet \& Mahé (1991), thermal gradients between shelf (depth 56 to $90 \mathrm{~m}$ ) and slope $(271$ to $365 \mathrm{~m})$ waters vary greatly among years (Table 1). In general, thermal gradients during cold years (1985-1990, as determined from Fig. 6) were twice as steep as thermal gradients in warm years (1978-1984). Late-winter temperatures on the shelf were often either well below $0^{\circ} \mathrm{C}(1985,1987,1989$, $1990)$ or well above $0^{\circ} \mathrm{C}(1978,1981,1983,1984)$. In contrast, thermal gradients between the shelf and slope in $3 \mathrm{~L}$ are relatively weak, in large part because of the Labrador Current which generally maintains temperatures below $0{ }^{\circ} \mathrm{C}$ on the shelf and below $4{ }^{\circ} \mathrm{C}$ on the slope throughout the year (Templeman 1975, Drinkwater \& Trites 1986). The average thermal gradient between shelf (57 to $92 \mathrm{~m}$ ) and slope (276 to $366 \mathrm{~m}$ ) from 1951 to 1971 (July data) is approximately $3.5^{\circ} \mathrm{C}$ (Templeman 1975) and varies little between warm and cold years. More importantly, temperatures on the shelf at 75 to $100 \mathrm{~m}$ rarely exceed $0^{\circ} \mathrm{C}$. For example, in 1979 (March), a warm year, the temperature difference between shelf $\left(-1\right.$ to $\left.0^{\circ} \mathrm{C}\right)$ and slope ( 3.3 to $3.4^{\circ} \mathrm{C}$ ) was about $4^{\circ} \mathrm{C}$ (MEDS database). This temperature difference is only slightly greater than the thermal gradient of approximately $2^{\circ} \mathrm{C}$ in a very cold year such as 1977 (July) (shelf: -1.6 to $0.7^{\circ} \mathrm{C}$; slope: 1.7 to $1.9^{\circ} \mathrm{C}$ ) (MEDS database).

It seems unlikely, then, that temperature will act as a thermal barrier to migration in $3 \mathrm{~L}$ because thermal gradients are generally low and vary little from year to year. Furthermore, given that cod that overwinter on the shelf are exposed, and presumably acclimatized, to sub-zero temperatures for much of the year, the pres- ence of such cold water at any specific time would not be expected to act as a significant deterrent to movement. The lack of a significant correlation between temperature and the shelf/slope biomass of cod supports this notion. However, low temperatures on northern Grand Bank would be expected to slow the maturation process, thereby delaying spawning, by reducing the rate of gonad development (Calder 1984, Davenport 1992). Low temperatures also appear to be the most important factor responsible for delayed spawning in herring (Lambert 1987, Ware \& Tanasichuk 1989) and in capelin Mallotus villosus (Carscadden et al. 1992). Thus, we attribute the negative correlation between temperature and spawning time in $3 \mathrm{~L}$ to the energetic constraint that low temperatures impose on physiological processes.

We propose that low temperatures (i.e. $<0^{\circ} \mathrm{C}$ ) on the shelf act as a thermal barrier to cod migrating from the slope in 3Ps and that the positive association between temperature and spawning time on St. Pierre Bank is due to increased rates of gonad development experienced by cod 'forced' to prolong their residence in warm slope waters. During those years identified as cold years in 3Ps (i.e. 1985-1990), temperatures on St. Pierre Bank during the period of gonad development did not exceed $1{ }^{\circ} \mathrm{C}$, being less than or equal to $-1{ }^{\circ} \mathrm{C}$ in 4 of the 6 years (Table 1). In contrast, temperatures of at least $0^{\circ} \mathrm{C}$ (often as high as 3 to $5^{\circ} \mathrm{C}$ ) always existed on St. Pierre Bank during the warm years (i.e. 1978-1984). The hypothesis that low temperatures deter migration from the slope to the shelf is supported by the observation that, relative to the slope, cod biomass on the shelf during the cold post-1984 years was, on average, 1 order of magnitude less than cod biomass on the shelf during the warm pre-1985 years. This difference in relative shelf cod biomass was highly significant (combined Canadian and French data: mean $\log _{10}$-shelf/slope biomass ( \pm SD) from 1978 to 1984 and 1985 to 1991 was $0.13 \pm 0.37$ and $-0.85 \pm 0.68$, respectively; $F_{\{1,21\}}=15.64, \mathrm{p}=$ 0.001 ). In all likelihood, these differences in biomass reflect true changes in the timing of migration to spawning areas. Changes in biomass cannot be attributed to fishing-induced changes in abundance because the total number of cod (shelf and slope data combined) did not differ between the warm and cold year periods. This was true for both the French and Canadian research data: French abundance estimates (mean \pm SD) for 1978 to 1984 and 1985 to 1991 were $6699 \pm 5832$ and $6532 \pm 5430$, respectively $\left(F_{[1,12)}=\right.$ $0.01, \mathrm{p}=0.96) ;$ Canadian abundance estimates for the same time periods were $5503 \pm 1075$ and $9106 \pm 6031$, respectively $\left(F_{[1.12]}=2.42, \mathrm{p}=0.15\right)$.

During periods of low sub-zero temperatures on St. Pierre Bank, cod appear to delay their spawning 
migration onto the shelf and to prolong their time of residence in slope waters. By remaining in the considerably warmer slope waters, gonad development would occur at a higher rate, leading to an earlier date at which females would be physiologically capable of spawning and presumably to an earlier date of spawning. This would account for the positive correlation observed between water temperature and spawning date in 3Ps. This raises the possibility that, if slope waters are always warmer than shelf waters, cod may always mature in the warm slope waters prior to migrating onto the shelf to spawn. The data, however, suggest otherwise. If cod normally spend the months immediately preceding spawning in slope waters, we would expect, at worst, either no correlation to exist between either spawning time or shelf/slope cod biomass and temperature, or we would expect to find negative (physiological constraint) and positive (migration constraint) associations, respectively. Neither set of associations was documented here. Thus, in the absence of changes in total cod abundance, we conclude that the observed changes in cod biomass between shelf and slope waters with changes in water temperature provide strong evidence that sub-zero temperatures on St. Pierre Bank during late winter and early spring act as a thermal barrier to cod migration and result in longer residence times by cod in the warm slope waters prior to spawning on the shelf.

Avoidance of sub-zero temperatures on St. Pierre Bank by mature cod may be related to their ability to produce plasma antifreeze glycoproteins (to prevent freezing of tissue fluids; Fletcher et al. 1987) and the potential physiological costs of doing so. Exposure to temperatures less than $0^{\circ} \mathrm{C}$ is required before adult

Table 1. Interannual variability in the range of temperatures on the continental shelf ( 56 to $90 \mathrm{~m}$ depth) and continental slope $(271$ to $365 \mathrm{~m}$ ) in NAFO Division 3Ps. Data are from hydrographic surveys conducted by French research vessels along a single transect (see Fig. 1) and are described in detail by Moguedet \& Mahé (1991)

\begin{tabular}{|llrr|}
\hline \multirow{2}{*}{ Year } & Date & \multicolumn{2}{c|}{$\begin{array}{c}\text { Temperature range }\left({ }^{\circ} \mathrm{C}\right) \\
\text { Shelf }\end{array}$} \\
\hline 1978 & March 14-19 & $-1<x \leq 5$ & $7 \leq x<9$ \\
1979 & March 7-8 & $-1<x \leq 0$ & $6<x \leq 7$ \\
1981 & March 11-21 & $1 \leq x \leq 3$ & $7 \leq x<9$ \\
1982 & March 12-19 & $-1 \leq x \leq 0$ & $3<x<5$ \\
1983 & February 26-March 2 & $0 \leq x \leq 3$ & $5<x<6$ \\
1984 & March 15-18 & $1 \leq x \leq 4$ & $6 \leq x<9$ \\
1985 & March 13-14 & $x<-1$ & $6<x \leq 7$ \\
1986 & February 21-22 & $-1<x<0$ & $6<x<8$ \\
1987 & March 5-6 & $x \leq-1$ & $6 \leq x<7$ \\
1988 & March 7-8 & $0 \leq x \leq 1$ & $4 \leq x \leq 6$ \\
1989 & March 9-10 & $x \leq-1$ & $3<x<5$ \\
1990 & March 12-13 & $x \leq-1$ & $6 \leq x \leq 7$ \\
& & & \\
\hline
\end{tabular}

cod will produce antifreeze glycoproteins (Fletcher et al. 1987). Given that it may take up to 2 mo for plasma ionic concentrations to attain a new equilibrium (Fletcher 1981, Fletcher et al. 1987), the physiological costs of migration into sub-zero temperature water may be prohibitive. The limited ability of adult cod to prevent freezing at temperatures less than $-1.2^{\circ} \mathrm{C}$ (Goddard et al. 1992) should also favour avoidance of the extremely low temperatures that dominate St. Pierre Bank in some years (e.g. 1985 , 1987, 1989, 1990; Table 1). On the basis of these experiments and on Bull's (1936, 1951) demonstration that cod can distinguish temperatures differing by less than $0.1^{\circ} \mathrm{C}$, Goddard et al. (1992) hypothesized that the high sensitivity of cod to the thermal characteristics of their surroundings should enable them to detect and, where the option exists (e.g. in 3Ps but perhaps to a lesser extent in 3L), avoid very cold water. The data on temperature and shelf/slope cod biomass documented here for 3Ps are consistent with this hypothesis.

The influence of temperature on both spawning date and the biomass of cod on the shelf (relative to that on the slope), in conjunction with experimental work on the production of plasma antifreeze proteins, provides strong evidence for the conclusion that low temperature can act as a thermal barrier to mature migrating cod and as an energetic constraint on the rate of gonad development. Where steep thermal gradients exist between shelf and slope waters (e.g. St. Pierre Bank spawning cod in $3 \mathrm{Ps})$, low temperatures $\left(<0^{\circ} \mathrm{C}\right)$ on the shelf force cod to undergo gonad development in very warm slope waters $\left(6\right.$ to $\left.9^{\circ} \mathrm{C}\right)$. As a consequence, individuals attain a readiness to spawn earlier than they would if they had undergone most of their gonad development at the 0 to $3^{\circ} \mathrm{C}$ they would have experienced on the shelf in years in which thermal barriers to cod migration were absent. In areas in which steep thermal gradients between shelf and slope waters are rare, or in areas in which temperatures vary little on a seasonal basis (e.g. northern Grand Bank spawning cod in 3L), the opportunity for fish to avoid particularly low temperatures will be limited, thus reducing the ability of temperature to act as a thermal barrier to migration and increasing the likelihood that the rate of gonad development will be highly dependent on ambient water temperature. In summary, our analyses indicate that the timing of cod reproduction off Newfoundland varies significantly among years, demonstrate how the effects of temperature on cod reproduction depend upon the hydrography of the region, and underscore the importance of separating sampling variability and interannual variation in age structure from true interannual variability in spawning time. 
Acknowledgements. The research was funded by the Northern Cod Science Programme and could not have been conducted without the research surveys undertaken by the Gadoid Section of the Groundfish Division, Canadian Department of Fisheries and Oceans. We thank Noel Cadigan for calculating the standard error estimates of spawning time appropriate for cluster sampling. We are grateful to Ken Drinkwater and Nicholas Barrowman for compiling and organizing the temperature data for 3Ps. Michael Fogarty, David Methven, Ken Drinkwater, Gordon Mertz, and Nancy Shackell provided very helpful comments on earlier versions of the manuscript.

\section{LITERATURE CITED}

Baird, J. W., Bishop, C. A., Brodie, W. B., Murphy, E. F. (1992) An assessment of the cod stock in NAFO divisions $2 \mathrm{~J} 3 \mathrm{KL}$. N. Atlant. Fish. Org. SCR Doc. 92/18

Bishop, C. A., Baird, J. W., Murphy, E. F. (1991). An assessment of the cod stock in NAFO Subdivision 3Ps. Can. Atl. Fish. Sci. Advis. Comm. Res. Doc. 91/36

Bull, H. O. (1936). Studies on conditioned responses in fishes. Part VII. Temperature perception in teleosts. J. mar. Biol Ass. U.K. 21: 1-28

Bull, H. O. (1951). An evaluation of our knowledge of fish behaviour in relation to hydrography. Rapp. Cons. int Explor. Mer 131: 8-23

Calder, W. A. (1984). Size, function, and life history. Harvard University Press, Harvard

Carscadden, J, Frank, K. T., Nakashima, B. S. (1992). Why was inshore capelin (Mallotus villosus) spawning delayed during 1991? Can. Atl. Fish. Sci. Advis. Comm. Res. Doc $92 / 61$

Cushing, D. H. (1969). The regularity of the spawning season of some fishes. J. Cons. int. Explor. Mer 33: 81-97

Davenport, J. (1992). Animal life at low temperature. Chapman \& Hall, London

Drinkwater, K. F., Trites, R. W. (1986). Monthly means of temperature and salinity in the Grand Banks region. Can. tech. Rep. Fish. Aquat. Sci. 1450

Ellertsen, B., Solemdal, P. (1990). Spawning strategy and a mechanism for adaptive larval production in ArctoNorwegian cod. ICES-C.M.1990/L:100

Elliott, J. M. (1993). A 25-year study of production of juvenile sea-trout, Salmo trutta, in an English Lake District stream. In: Gibson, R. J., Cutting, R. E. (eds.) Production of juvenile Atlantic salmon, Salmo salar, in natural waters. Can. Spec. Publ. Fish. Aquat. Sci. 118

Fletcher, G. L. (1981). Effects of temperature and photoperiod on the plasma freezing point depression, $\mathrm{Cl}^{-}$concentration, and protein 'anti-freeze' in winter flounder Can J. Zool. 59: 193-201

Fletcher, G. L., King, M. J., Kao, M. H. (1987). Low temperature regulation of antifreeze glycopeptide levels in Atlantic cod (Gadus morhua). Can. J. Zool. 65: 227-233

Gavaris, S. (1980). Use of a multiplicative model to estimate catch rate and effort from commercial data. Can. J. Fish. Aquat. Sci. 37: 2272-2275

Goddard, S. V., Kao, M. H., Fletcher, G. L. (1992). Antitreeze production, freeze resistance, and overwintering of juvenile northern Atlantic cod (Gadus morhua). Can. J. Fish. Aquat. Sci. 49: 516-522

Grant, P. R. (1986). Ecology and evolution of Darwin's finches. Princeton University Press, Princeton

Hutchings, J. A., Myers, R. A. (1993). The effect of age on the seasonality of maturation and spawning of Atlantic cod,
Gadus morhua, in the Northwest Atlantic. Can. J. Fish. Aquat. Sci. 50: 2468-2474

Hutchings, J. A., Myers, R. A., Lilly, G. R. (1993). Geographic variation in the spawning of Atlantic cod, Gadus morhua in the Northwest Atlantic. Can. J. Fish. Aquat. Sci. 50 $2457-2467$

Jónsson, E. (1982). A survey of spawning and reproduction of the Icelandic cod. Rit Fiskideildar 6

Kjesbu, O. S. (1989). The spawning activity of cod, Gadus morhua L. J. Fish Biol. 34: 195-206

Lambert, T. C. (1987). Duration and intensity of spawning in herring Clupea harengus as related to the age structure of the mature population. Mar. Ecol. Prog. Ser. 39: 209-220

Moguedet, P., Mahé, J. C. (1991). Yearly variations in water temperature in NAFO Subdivision 3Ps from 1978 to 1990. N. Atlant. Fish. Org. SCR Doc. 91/24

Myers, R. A., Hutchings, J. A., Gibson, R. J. (1986). Variation in male parr maturation within and among populations of Atlantic salmon, Salmo salar. Can. J. Fish. Aquat. Sci. 43 $1242-1248$

Myers, R. A., Mertz, G., Bishop, C. A. (1993). Cod spawning in relation to physical and biological cycles of the northern Northwest Atlantic. Fish. Oceanogr. 2: 154-165

Page, F. H., Frank, K. T. (1989). Spawning time and egg stage duration in northwest Atlantic haddock (Melanogrammus aeglefinus) stocks with emphasis on Georges and Browns Bank. Can. J. Fish. Aquat. Sci. 46 (Suppl. 1): 68-81

Pedersen, $T$ (1984). Variation of peak spawning of Arcto-Norwegian cod (Gadus morhua L.) during the time period 1929-1982 based on indices estimated from fishery statistics. In: Dahl, E., Danielssen, D. S., Moksness, E., Solemdal, P. (eds.) The propagation of cod Gadus morhua L. Flødevigen rapportser. 1, Arendal, p. 301-316

Petrie, B., Loder, J. W., Lazier, J., Akenhead, S. A. (1992). Temperature and salinity variability on the eastern Newfoundland shelf: the residual field. Atmos. Ocean. 30: $120-139$

Rao, J. N. K., Scott, A. J. (1992). A simple method for the analysis of clustered binary data. Biometrics 48: $577-585$

Rijnsdorp, A. D. (1989). Maturation of male and female North Sea plaice (Pleuronectes platessa L.). J. Cons. int. Explor Mer 46: 35-51

Sinclair, M., Tremblay, M. J. (1984). Timing of spawning of Atlantic herring (Clupea harengus harengus) populations and the match-mismatch theory. Can. J. Fish. Aquat. Sci. 41: 1055-1065

Sokal, R. R., Rohlf, F. J. (1981). Biometry. Freeman, San Francisco

Sætersdal, G., Loeng, H. (1987). Ecological adaptation of reproduction in northeast Arctic cod. Fish. Res. 5: $253-270$

Templeman, W. (1962). Divisions of cod stocks in the Northwest Atlantic. Int. Comm. Northw. Atlant. Fish. Redbook Part III: $79-129$

Templeman, W. (1974). Migrations and intermingling of Atlantic cod (Gadus morhua) stocks of the Newfoundland area. J. Fish. Res. Bd Can. 31 1073-1092

Templeman, W. (1975). Comparison of temperatures in July-August hydrographic sections of the eastern Newfoundland area in 1972 and 1973 with those from 1951 to 1971. Int. Comm. Northw. Atlant. Fish. Spec. Publ. 10: $17-31$

Templeman, W. (1979). Migration and intermingling of stocks of Atlantic cod, Gadus morhua, of the Newfoundland and adjacent areas from tagging in 1962-66. Int. Comm. Northw. Atlant. Fish. Res. Bull. 14 
Templeman, W., Fleming, A. M. (1962). Cod tagging in the Newfoundland area during 1947 and 1948. J. Fish. Res. Bd Can. 19: 445-487

Templeman, W., Hodder, V. M., Wells, R. (1978). Sexual maturity and spawning in haddock, Melanogrammus aegle-

This article was presented by R. L. Haedrich (Senior Editorial Advisor), St. John's, Nfld, Canada finus, of the southern Grand Bank. Int. Comm. Northw. Atlant. Fish. Res. Bull. 13: 53-65

Ware, D. M., Tanasichuk, R. W. (1989). Biological basis of maturation and spawning waves in Pacific herring (Clupea harengus pallasi). Can. J. Fish. Aquat. Sci. 46: 1776-1784

Manuscript first received: June 15, 1993

Revised version accepted: January 25, 1994 